\title{
Survival probabilities of loggerhead sea turtles (Caretta caretta) estimated from capture-mark-recapture data in the Mediterranean Sea
}

\author{
PAOLO CASALE ${ }^{1}$, ANTONIOS D. MAZARIS ${ }^{2}$, DANIELA FREGGI ${ }^{3}$, ROBERTO BASSO $^{4}$ \\ and ROBERTO ARGANO ${ }^{1}$ \\ ${ }^{1}$ Dipartimento di Biologia Animale e dell’Uomo, Università "La Sapienza", 00185 Roma, Italy. \\ E-mail: paolo.casale@tiscali.it \\ ${ }^{2}$ Biodiversity Conservation Laboratory, Department of Environmental Studies, University of the Aegean, \\ 81100 Mitilene, Greece. \\ ${ }^{3}$ Sea Turtle Rescue Centre WWF Italy, CP 92010 Lampedusa, Italy. \\ ${ }^{4}$ Museo Civico di Storia Naturale di Jesolo, Via Bafile 17230017 Jesolo Lido, Italy.
}

SUMMARY: Survival probabilities of loggerhead sea turtles (Caretta caretta) are estimated for the first time in the Mediterranean by analysing 3254 tagging and 134 re-encounter data from this region. Most of these turtles were juveniles found at sea. Re-encounters were live resightings and dead recoveries and data were analysed with Barker's model, a modified version of the Cormack-Jolly-Seber model which can combine recapture, live resighting and dead recovery data. An annual survival probability of $0.73(\mathrm{CI} 95 \%=0.67-0.78 ; \mathrm{n}=3254)$ was obtained, and should be considered as a conservative estimate due to an unknown, though not negligible, tag loss rate. This study makes a preliminary estimate of the survival probabilities of in-water developmental stages for the Mediterranean population of endangered loggerhead sea turtles and provides the first insights into the magnitude of the suspected human-induced mortality in the region. The model used here for the first time on sea turtles could be used to obtain survival estimates from other data sets with few or no true recaptures but with other types of re-encounter data, which are a common output of tagging programmes involving these wide-ranging animals.

Keywords: loggerhead sea turtle, survival, capture-mark-recapture, Mediterranean, Barker's model.

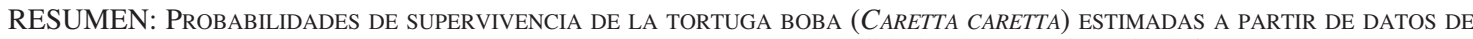
CAPTURA-MARCADO-RECAPTURA EN EL MAR MEDITERRÁNEO. - Las probabilidades de supervivencia de la tortuga boba (Caretta caretta) se han estimado por primera vez en el Mediterráneo analizando datos de 3254 marcajes y 134 recapturas en esta región. La mayoría de las tortugas eran juveniles encontrados en el mar. Las recapturas fueron reavistamientos de individuos vivos y recuperaciones de individuos muertos. Los datos se analizaron mediante el modelo de Baker, versión modificada del de Cormack-Jolly-Seber que puede combinar recaptura, reavistamientos de individuos vivos e individuos recuperados muertos. Se obtuvo una probabilidad de supervivencia anual de 0.73 (IC $95 \%=0.67-0.78 ; n=3254$ ), y debe considerarse como una estima conservativa debido a una desconocida, aunque no insignificante, tasa de perdida de marcados. Este estudio ofrece una estima preliminar de las probabilidades de supervivencia de los estadios de desarrollo "en el mar" para la población mediterránea amenazada de tortuga boba marina, y proporciona las primeras observaciones sobre la magnitud de la sospechada mortalidad inducida por el hombre en la región. El modelo, utilizado aquí por primera vez en tortugas marinas podría ser utilizado para obtener estimas de supervivencia a partir de otros datos con pocas o sin recapturas reales, pero con otros tipos de datos de recaptura frecuentemente producidos por programas de marcado de estos animales de amplia distribución.

Palabras clave: tortuga boba, supervivencia, captura-marcado-recaptura, Mediterráneo, modelo de Barker. 


\section{INTRODUCTION}

Loggerhead sea turtles (Caretta caretta) are listed as Endangered in the IUCN Red List of Threatened Species. In the Mediterranean Sea, they represent the most abundant species of marine turtles. Genetic evidence supports partial isolation, at least at the female level, between Mediterranean and Atlantic loggerheads (Bowen et al., 1993, Laurent et al., 1998), with the presence of sub-populations across the Mediterranean basin (Schroth et al., 1996; Laurent et al., 1998). Nesting sites and neritic habitats are basically restricted to the eastern Mediterranean, while oceanic stage turtles frequent areas throughout the entire basin (Margaritoulis et al., 2003). By-catch mortality is considered a serious threat in the Mediterranean (Gerosa and Casale, 1999), potentially leading to steep population losses while degradation, fragmentation and loss of nesting habitat due to tourist development, industry and agricultural encroachment are also generally considered as critical factors threatening this species' reproductive performance (Lutcavage et al., 1997), and thus negatively impacting future generations. Though our knowledge of loggerhead turtles in the Mediterranean has improved significantly during recent years (see Margaritoulis et al., 2003), several aspects, such as population trends and individual survival probabilities, remain unquantified. In the context of a presumed great anthropogenic impact on the populations, such information is of the utmost importance for the conservation of sea turtles in the region. In particular, survival probabilities are probably directly affected by the most important anthropogenic mortality: the incidental capture by fishing gear. Sea turtles are long-lived animals, with a high mortality in the first period of life and with the highest survival probability in the adult phase (Heppell et al., 2003a). Due to the relatively long duration of the immature phase, the survival probability of juveniles has the highest effect on sea turtle population dynamics (Heppell et al., 2003b).

Common approaches to estimating life history parameters are primarily based on extensive tagging programmes at sea turtle nesting rookeries focusing on nesting females (Chaloupka and Musick, 1997). This method has been applied to several nesting sites, but unfortunately it does not provide any information on the elusive juvenile phase of sea turtles (Heppell et al., 2003a). In this respect, survival probabilities of juvenile sea turtles have been esti- mated by several methods such as "catch curve analysis' (Frazer, 1987; Epperly et al., 2001; Bjorndal et al., 2003b), or by deduction using available demographic information under the debatable assumption that populations are stable (Frazer, 1983; Chaloupka, 2003).

Capture-mark-recapture (CMR) studies have been suggested as an alternative method that could provide demographic information for several life history stages, and additionally be used for estimating population size. CMR studies investigating survival probability have been conducted on Caretta caretta and other sea turtle species in various locations throughout the world (see Heppell et al., 2003a for a review; Chaloupka and Limpus, 2005; Bjorndal et al., 2003a; Seminoff et al., 2003). However, this type of approach requires intensive and long-lasting field work, so such data are limited.

The present study was designed to provide an estimate of annual survival probabilities of loggerhead turtles in the Mediterranean, and in particular of the juvenile phase, by using results of a tagging programme carried out in Italy. The 23-year data collected during this study are the only long-term observational data on loggerhead sea turtles at sea (mostly juveniles) in the Mediterranean. This sea has the particular condition of an almost closed basin, thus potentially enhancing re-encounter opportunities in this kind of study, and Italy is in a favourable, central geographical position. Our data were processed using a modified version of the CJS model to take into account a variety of re-encounter types.

\section{MATERIALS AND METHODS}

\section{Data collection}

Over a 23-year period (1981-2003), 3254 loggerhead turtles were tagged and released from different sites, primarily around Italy. These specimens were originally captured by fishing gears, found stranded, gathered from the sea or found while nesting, most within the framework of an Italian tagging and awareness programme (Argano, 1992).

Individuals were measured (curved carapace length notch to tip, CCLn-t; Bolten, 1999) and tagged with monel or inconel tags (styles 49 or 681, National Band and Tag, Kentucky, USA), which were attached to one or both front flippers. After release, during the 


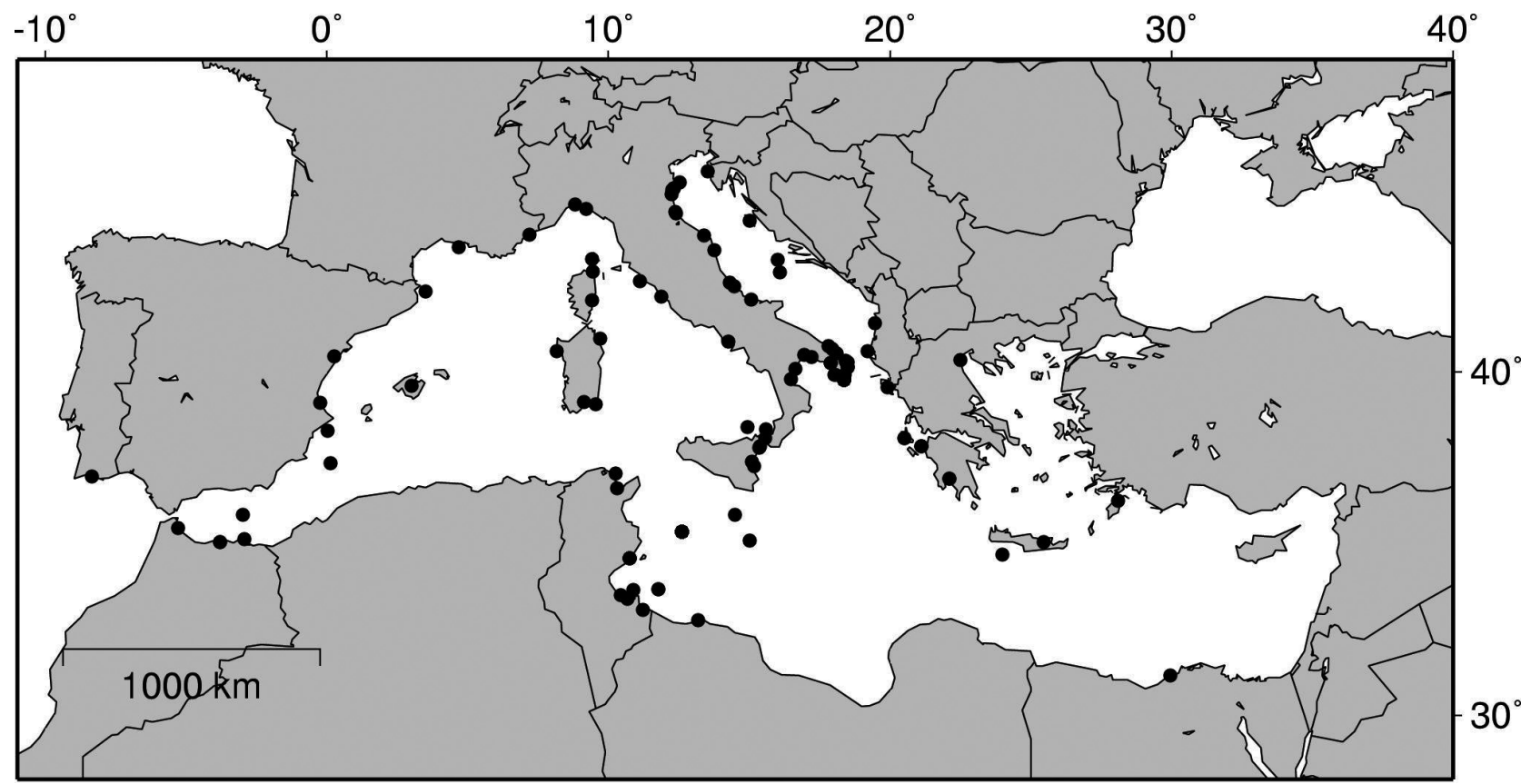

FIG. 1. - Study area. Turtles were found, tagged, and released in the waters around Italy. 134 of them were then reencountered at different sites in the Mediterranean (dots).

23-year period of the study a total of 134 turtles were re-encountered in the same kind of circumstances as above, in waters and coasts of Italy and/or other Mediterranean countries (Fig. 1). These turtles were re-encountered only one time, except one that was reencountered twice. Size at first release ranged between 25 and $88 \mathrm{~cm} \mathrm{CCL}$ ( mean $=54.4 ; \mathrm{SD}=13.1$; $\mathrm{n}=127)$. This means that most of these turtles were likely to be immature. In fact, the average female probably starts breeding at a size slightly smaller than the average size of nesting females (Limpus, 1990), which in the Mediterranean ranges between 66.5 and $84.7 \mathrm{~cm}$ CCL (depending on the nesting site; Margaritoulis et al., 2003), and in the Mediterranean males probably reach maturity around $75-80 \mathrm{~cm} \mathrm{CCL}$ (Casale et al., 2005).

\section{Data analysis}

CMR data has been typically used to estimate 'annual survival probabilities' through the CormackJolly-Seber (CJS) survival model (Cormack, 1964; Jolly, 1965; Seber, 1965). The CJS model theory is based on live recaptures of marked animals, within which the frequencies of survival and capture probabilities are used for model development (Pollock et al., 1990; Leberton et al., 1992).

Since our data were obtained from a variety of sources, including both dead and live animals, we used a joint analysis developed by Barker (1997) to incorporate all sources of information. The model was implemented using the MARK program (White and Burnham, 1999; Cooch and White, 2002).

The advantages of using a combination of alternative data sources have led to the extension of the traditional Cormack-Jolly-Seber method and resulted to the development of several additional models. The one developed by Burnham (1993) represents the first formal joint analysis that combines live recaptures and dead recovery, and it has been applied in sea turtle CMR studies (e.g. Bjorndal et al., 2003a; Seminoff et al., 2003). Barker (1997) further extended the model to allow the joint analysis of the different types of information under the case of random temporary emigration (Barker, 1999; Barker and White, 2001; Barker et al., 2004). This model represents a generalisation and extension of the traditional CJS model that focuses on the estimation of survival probabilities rather than population size (Barker and White, 2001). With this model, information from live sighting data can be used in addition to live recapture and dead recovery, allowing re-encounter data to be obtained at any time following the marking occasion. A key feature of Barker's model is that in addition to the estimates of survival and capture probabilities it also provides the basic statistics for estimates of resighting probabilities. 
The model considers seven parameters (Barker and White, 2001):

$\mathrm{S}_{i}=$ survival probability

$\mathrm{p}_{i}=$ capture probability

$\mathrm{r}_{i}=$ probability of a dead marked animal being found and reported

$\mathrm{R}_{i}=$ probability of a live marked animal being resighted

$\mathrm{R}_{i}{ }_{i}=$ probability of an animal being resighted alive before it dies

$\mathrm{F}_{i}=$ probability of animals being at risk of capture if they were at risk of capture in the previous period

$\mathrm{F}_{i}{ }_{i}=$ probability of animals being at risk of capture if they were not at risk of capture in the previous period

Recovery and resighting probabilities are independent from the study's sampling effort. In fact, they are the result of several probabilities: the turtle is found by someone; the finder understands the message on the tag; the finder wishes to report the finding; the finder is not afraid of reporting the finding (e.g. if the finder is a fishermen and the turtle has died); the finder has the resources or skills to write and send a letter or to report the finding in other ways. The large geographical scales such as those at which tagged turtles move inevitably have some heterogeneity in human density and activity, culture, and economy which could affect reporting probability to some extent.

In addition to the usual assumptions of the JollySeber model, Baker's model assumes that: (a) resightings are made throughout the range of the study animal, but captures only where they are at risk of capture; (b) all animals have common $\mathrm{S}$ regardless of whether they are in the part of the range where they are at risk of capture; (c) all animals that are alive at time $\mathrm{i}$ have common $\mathrm{r}, \mathrm{R}$, and R'; (d) all animals have common F and F'.

As described above, our study had no capture phases in the strict sense of CMR studies, so reencounters are better classified as live resightings and dead recoveries only, without true recaptures. For this reason we set the recapture probability at $\mathrm{p}$ $=0$ and the related movement probabilities (movement in and out the part of the range where animals are at risk of capture) at $F^{\prime}=F^{\prime}=1$. This also relaxes the basic model's assumptions concerning the capture phase/range. With these three parameters fixed, four parameters were left free.

In order to fit the model, we divided our continuous 23-year study period into one-year sampling intervals, arbitrarily ranging from 1 January to 31 December, in which live resightings and dead recoveries occurred. Based on this method 23 sampling occasions (one for each year: 1981 to 2003) were produced and included in the analysis. In the MARK program, a dataset for Barker's model is coded with a capture and a re-encounter slot in each year. For instance, the case of a turtle tagged in year 8 and reencountered alive in year 12 was coded as: 00000000000000100000000200000000000000000 00000 . However, in this way the first survival period would be assumed to be one-year long, which is not the case actually. In fact, the real first survival period begins at release, which is not always 1 January but any date during the year, so it is shorter then one year, an aspect considered by previous studies (e.g. Tavecchia et al., 2001). In order to deal with this aspect, we considered the first survival period (year 1) as an independent period and introduced individual time covariates as number of days from the beginning of this period (1 January) to release. When this factor is taken into account, two age classes (one for the first period, and one for the remaining period) were specified and included in the model, so an age-dependent $\mathrm{S}$ was estimated for the first year, and either a constant or a time-dependent $\mathrm{S}$ was estimated for all the other year-periods (2 to $\mathrm{n})$. When the time at release is not taken into account, $\mathrm{S}$ was not age-dependent but either constant or time-dependent.

Fifteen different models (Table 1) were developed considering either one or two age classes for survival probability (the first age class as described above) and treating the four variable parameters (survival, reporting and the two resighting probabilities) either as time-dependent or constant through time.

The AICc (corrected Akaike's Information Criterion) was used in our analysis to assess the adequacy of the developed models. The fittest model was selected based on the minimum values of AICc. A bootstrap goodness of fit test (GOF) (100 iterations) was also performed to investigate the presence of any significant deviation of the general model for our data.

\section{RESULTS}

Among the 15 models developed, the one which represents the best compromise between model complexity and data fit (lowest AICc) (Table 1; 
TABLE 1. - The 15 models developed for estimating survival probabilities from the sample. For each model the following information is given: number of parameters (Par), Model Likelihood, corrected Akaike's Information Criterion (AICc), differences in AICc value from the best model ( $\triangle \mathrm{AICc}$ ), AICc Weights, and Deviance (see Cooch and White, 2002, for details). AICc and Deviance are expressed as X-1600. Description of the characteristics of the model for each parameter is also provided: (.) constant through time; (t) time-dependent different in each year; * 2 age classes. See text for details.

\begin{tabular}{|c|c|c|c|c|c|c|c|}
\hline Model & Model description & Par & Model Likelihood & $\mathrm{AICc}$ & $\triangle \mathrm{AICc}$ & AICc Weights & Deviance \\
\hline 1 & $\mathrm{~S}(.) \mathrm{r}(\mathrm{t}) \mathrm{R}(.) \mathrm{R}^{\prime}()$. & 26 & 150 & 0 & 0.59984 & 1 & 98 \\
\hline 2 & S(t) r(.) R(.) R'(.) & 26 & 151 & 1 & 0.39856 & 0.6644 & 99 \\
\hline 3 & $\mathrm{~S}(.) \mathrm{r}(.) \mathrm{R}(.) \mathrm{R}^{\prime}()$. & 4 & 162 & 12 & 0.00154 & 0.0026 & 154 \\
\hline 4 & $\mathrm{~S}(). * \mathrm{r}(.) \mathrm{R}(.) \mathrm{R}^{\prime}()$. & 5 & 164 & 13 & 0.0007 & 0.0012 & 154 \\
\hline 5 & $\mathrm{~S}(.)^{*} \mathrm{r}(\mathrm{t}) \mathrm{R}(.) \mathrm{R}^{\prime}()$. & 27 & 169 & 19 & 0.00005 & 0.0001 & 115 \\
\hline 6 & $\mathrm{~S}(.) \mathrm{r}(.) \mathrm{R}(\mathrm{t}) \mathrm{R}^{\prime}()$. & 26 & 176 & 26 & 0 & 0 & 124 \\
\hline 7 & $\mathrm{~S}(.) \mathrm{r}(.) \mathrm{R}(.) \mathrm{R}^{\prime}(\mathrm{t})$ & 26 & 179 & 28 & 0 & 0 & 126 \\
\hline 8 & $\mathrm{~S}(\mathrm{t}) * \mathrm{r}(.) \mathrm{R}(.) \mathrm{R}^{\prime}()$. & 26 & 194 & 43 & 0 & 0 & 141 \\
\hline 9 & $\mathrm{~S}(\mathrm{t})^{*} \mathrm{r}(\mathrm{t}) \mathrm{R}(.) \mathrm{R}^{\prime}()$. & 48 & 198 & 48 & 0 & 0 & 101 \\
\hline 10 & $\mathrm{~S}\left(\right.$.) $\mathrm{r}(\mathrm{t}) \mathrm{R}(\mathrm{t}) \mathrm{R}^{\prime}(\mathrm{t})$ & 70 & 206 & 55 & 0 & 0 & 63 \\
\hline 11 & $S^{\prime}(\mathrm{t}) r^{\prime}() R.(t) R^{\prime}(t)$ & 70 & 211 & 61 & 0 & 0 & 68 \\
\hline 12 & $\mathrm{~S}(.) \mathrm{r}\left(\right.$.) $\mathrm{R}(\mathrm{t}) \mathrm{R}^{\prime}(\mathrm{t})$ & 48 & 217 & 67 & 0 & 0 & 120 \\
\hline 13 & $\mathrm{~S}(.)^{*} \mathrm{r}(\mathrm{t}) \mathrm{R}(\mathrm{t}) \mathrm{R}^{\prime}(\mathrm{t})$ & 71 & 223 & 73 & 0 & 0 & 78 \\
\hline 14 & $\mathrm{~S}(\mathrm{t})^{*} \mathrm{r}(\mathrm{t}) \mathrm{R}(\mathrm{t}) \mathrm{R}^{\prime}(\mathrm{t})$ & 92 & 227 & 77 & 0 & 0 & 38 \\
\hline 15 & $S(t) r(t) R(t) R^{\prime}(t)$ & 92 & 236 & 86 & 0 & 0 & 47 \\
\hline
\end{tabular}

Model 1) has no age classes, constant survival probability (S), constant resighting probabilities ( $\left.R, R^{\prime}\right)$ and time-dependent reporting probabilities. The bootstrap GOF test showed no significant deviation either in this model $1(\mathrm{p}=0.53 ; \hat{\mathrm{c}}=0.99)$ or in the most general model $15(\mathrm{p}=0.36 ; \hat{\mathrm{c}}=1.28)$. Annual survival probability was estimated as 0.73 (CI 95\% $=0.67-0.78 ; n=3254)$. The estimates for the other parameters $\left(\mathrm{r}_{1-23}=0.00-0.18 ; \mathrm{R}=0.0042 ; \mathrm{R}^{\prime}=\right.$ 0.010 ) indicate low dead reporting and live resighting probabilities, which is what was expected considering the dispersal of juveniles in the Mediterranean (Fig. 1) and the size of the populations targeted.

\section{DISCUSSION}

An apparently low number of re-encounters was obtained during this study. However, this is the rule in similar tagging programmes which do not capture specimens in high-fidelity specific sites, such as nesting beaches or special feeding spots, and rely on opportunistic re-encounters and reports. Moreover, our study area was in the centre of the Mediterranean and tagged animals dispersed in a wide range (Fig. 1). Accordingly, comparable low probabilities of dead recoveries $(r=0.088$, slightly greater then our ones) were obtained by a similar study collecting re-encounters from throughout the Greater Caribbean (Bjorndal et al., 2003a). Since no other studies used Barker's model on sea turtles, other resighting probabilities are not available for comparison. The fittest model included a timedependent reporting probability. Other studies observed such time-dependency (e.g. Frederiksen and Bregnballe, 2000), and a temporal change in the cause of mortality is one of the possible reasons (Schaub and Pradel, 2004).

Based on the size distribution of released animals, the sample used in the analysis primary consists of immature turtles. Sea turtles are long maturing animals, and immatures pass through different life stages (oceanic and neritic) in which different causes of mortality occur (Heppell et al., 2003a). As a consequence, the survival probability estimated here is likely to be the result of different stage-specific survival probabilities.

Furthermore, this survival probability includes both natural and human-induced mortality, which are very difficult to distinguish in such studies, although unknown human-induced mortality is certainly not negligible in the region. For instance, sea turtle stranding networks in the Mediterranean reported high proportions of turtles with evidence of anthropogenic impact (e.g. Kopsida et al., 2002; Casale et al., in press).

Our estimate $(0.73)$ is in the range of estimates available from other loggerhead turtle populations (ranging 0.67-0.92; table 2) and other sea turtle species (see Heppell et al., 2003a for a review; Chaloupka and Limpus, 2005; Bjorndal et al., 2003b; Seminoff et al., 2003), produced either directly from row data or derived by fitting population models. However, such comparisons should be taken with caution. This is primarily because life 
stages (e.g. oceanic juveniles, neritic juveniles, neritic adults) probably have different survival probabilities, due to factors like size-predation relationship, habitat type, reproductive investment and behaviour, while different populations differ both in size at recruitment to neritic grounds and size at maturity. Thus, survival probabilities are difficult to compare on the basis of size only. For instance, in the Mediterranean, loggerhead turtles (Caretta caretta) mature at a smaller size (range of means of nesting females: $66.5-84.7 \mathrm{~cm}$ CCL; Margaritoulis et al., 2003) than any other population (e.g. range of means of nesting females in the Atlantic: 98.9-105.1 cm CCL; in the Pacific: 80-114; Dodd, 1988) and recruit to neritic habitats at a small size too (e.g. Casale et al., 2004).

The relatively low estimates of annual survivorship observed should be regarded considering the assumptions and limitations of associated model development. One of the most important assumptions in CMR analysis is that markers are not lost, but it is also the most often violated assumption, because animals do lose markers. Thus, animal reencounters, and therefore model results, could be significantly affected by the frequency of tag loss. The tagging methods used in our programme very likely produced some tag loss, so we are relatively certain that our results are underestimated. Unfortunately, tag loss rate depends on several different factors, some associated with the area and habitat, and its assessment is not a simple task (Chaloupka and Musick, 1997). Thus, since no annual tag retention rates are available for our study area, correction of our survival estimates at the present time is not possible. In a different area (eastern Australia) tag loss for loggerhead turtles in feeding grounds tagged with the main method used in our study (monel 1005-49 NBT tags, applied in the middle of the front flipper) was estimated to be $100 \%$ after 11 years (Limpus, 1992), and in this respect it is interesting that the longest re-encounter period observed in our study was 10.9 years. Certainly, in order to improve the accuracy of the present estimate, it is essential to obtain accurate estimations of annual tag retention rates associated with future data sets from the region.

Notwithstanding the above limitations, the present results are of interest for conservation. In fact, they represent the first indication of survival probabilities in the Mediterranean basin, an area with major anthropogenic threats, notably fishery interaction. Assuming a natural survivorship no higher than 0.95 (Table 2) and a tag loss rate of around 0.1, the range 0.1-0.2 seems a reasonable figure for the additional human-induced mortality.

Although it requires great effort and a long time to estimate survival probabilities through CMR data, such information is fundamental in order to include population dynamics in the current conservation work for sea turtles in the Mediterranean. New approaches of intensive tagging at sea could be very helpful in this respect, especially through collaboration with fishermen that can be carried out in conjunction with awareness campaigns.

Joint analysis of live and dead encounter data has the main advantage of utilising additional

TABLE 2. - Mean survival probabilities of immature loggerhead turtles directly derived or produced by fitting population models. sGBR: southern Great Barrier Reef, CC: catch-curve analysis, CJS: Cormack-Jolly-Seber. CCL: curved carapace length.

\begin{tabular}{|c|c|c|c|c|c|}
\hline $\begin{array}{l}\text { Direct derived estimates } \\
\text { Location }\end{array}$ & Habitat & CCL & Survival probability & Method & Source \\
\hline $\begin{array}{l}\text { North Atlantic } \\
\text { Southeast US } \\
\text { Southeast US } \\
\text { sGBR, Australia } \\
\text { sGBR, Australia } \\
\text { sGBR, Australia }\end{array}$ & $\begin{array}{l}\text { Oceanic } \\
\text { Neritic } \\
\text { Neritic } \\
\text { Oceanic } \\
\text { Neritic } \\
\text { Neritic }\end{array}$ & $\begin{array}{c}20.5-65 \\
<35.3-88.6 \\
76.7 \\
\\
>91 \\
<95\end{array}$ & $\begin{array}{l}0.72 \\
0.7 \\
0.89 \\
0.83 \\
0.88 \\
0.92\end{array}$ & $\begin{array}{l}\text { CC } \\
\text { CC } \\
\text { CC } \\
\text { CJS } \\
\text { CJS } \\
\text { CJS }\end{array}$ & $\begin{array}{l}\text { Bjorndal et al., } 2003 \mathrm{~b} \\
\text { Frazer, } 1987 \\
\text { Epperly et al., } 2001 \\
\text { Heppell et al., } 1996 \\
\text { Chaloupka and Limpus, } 2002 \\
\text { Chaloupka and Limpus, } 2002\end{array}$ \\
\hline $\begin{array}{l}\text { Estimates from populatio } \\
\text { Stock }\end{array}$ & $\begin{array}{l}\text { models } \\
\text { Stage }\end{array}$ & CCL & Survival Probability & & Source \\
\hline $\begin{array}{l}\text { Atlantic } \\
\text { Atlantic } \\
\text { Atlantic } \\
\text { Atlantic } \\
\text { Atlantic } \\
\text { Atlantic } \\
\text { sGBR, Australia }\end{array}$ & $\begin{array}{l}\text { Oceanic } \\
\text { Oceanic } \\
\text { Small Neritic } \\
\text { Small Neritic } \\
\text { Large Neritic } \\
\text { Large Neritic } \\
\text { Oceanic }\end{array}$ & $\begin{array}{l}5-45 \\
5-45 \\
45-72 \\
45-72 \\
72-92 \\
72-92 \\
<78\end{array}$ & $\begin{array}{c}0.75 \\
0.88 \\
0.68 \\
0.7 \\
0.74 \\
0.8 \\
0.67\end{array}$ & & $\begin{array}{l}\text { Heppell et al., 2003b } \\
\text { Heppell et al., 2003b } \\
\text { Heppell et al., 2003b } \\
\text { Heppell et al., 2003b } \\
\text { Heppell et al., 2003b } \\
\text { Heppell et al., 2003b } \\
\text { Chaloupka, 2003 }\end{array}$ \\
\hline
\end{tabular}


sources of information to estimate population life history parameters. Barker's model allows the use of all additional types of data that could be available in a mark-recapture study. Despite the increase of model complexity due to the inclusion of extra parameters, such a model could lead to a significant improvement in the precision of the parameters estimated, whilst reducing sampling variances of the estimated parameters (e.g. Barker, 1997; Barker and White; 2001). It should also be mentioned that since the model represents an extension of the first joint live and dead encounter models with minor modifications, which actually involve the reduction of input parameters, the model corresponds to simpler mark-recapture models whilst allowing the relaxation of basic assumptions made by such models (for a detailed description see Barker 1997). Considering the migratory nature of sea turtles, but also the fact that sampling efforts in most sea turtle mark-recapture studies take place at different, relatively short time periods and are repeated after some period of time (for example see: Heppell et al., 1996; Bjorndal et al., 2003a; Chaloupka and Limpus, 2002), we suggest that Barker's model could be successfully applied to study species' population parameters, since it allows the inclusion of information of both live resighting and tag recovery data obtained at any time between these different sampling periods. This is particularly important for those sea turtle tagging programmes which, due to project design and geographical features of the area (like the Mediterranean), provide many reencounter data though few or no true recaptures. Thus, the use of this model could help to increase the availability of survival probabilities from existing tagging data sets.

\section{ACKNOWLEDGEMENTS}

This work was made possible thanks to the invaluable efforts of many individuals: all the fishermen who collaborated in the project; the students and volunteers who helped in the field work; the central and local authorities; and WWF-Italy. In particular, we thank: G. Gerosa (Chelon); M. Cocco, C. Jacomini, G. Cantoro, B. Cristo, C. Focarelli, G. Guerrasio, G. Paolillo, A. Piras, G. Rallo, D. Ricciardi, F. Sottile, V. Spica, M. Spoto and A. Vanadia (WWF-Italy); A. Di Natale (Acquario di Genova); P. Meschini (Acquario di Livorno); C.
Froglia (CNR Ancona); A.L. Stanzani (Fondazione Cetacea); A. Dominici and S. Nannarelli (Hydrosphera); G. Marzano (Museo di Storia Naturale del Salento di Calimera); V. Olivieri (Museo Ittico di Pescara); F. Bentivegna and S. Bocchetti (Stazione Zoologica di Napoli); A. Donato (Università di Messina); and M. Passarella. We also thank R. Barker for helpful suggestions on the data analysis and G. White for suggestions and technical help with the MARK program. Fig 1 was prepared with the Maptool program (SEATURTLE.ORG, www.seaturtle.org). Two anonymous referees provided useful comments for improving a previous version of the manuscript.

\section{REFERENCES}

Argano, R. - 1992. Sea turtles and monk seal in Italian seas: conservation and perspectives. Boll. Mus. Ist. Biol. Univ. Genova, 56-57: 113-135.

Barker, R.J. - 1997. Joint modeling of live-recapture, tag-resight, and tag-recovery data. Biometrics, 53: 666-677.

Barker, R.J. - 1999. Joint analysis of mark recapture, resighting and ring-recovery data with age-dependence and marking-effect. Bird. Study, 46: 82-90.

Barker, R.J., K.P. Burnham and G.C. White. - 2004. Encounter history modeling of joint mark-recapture, tag-resighting and tagrecovery data under temporary emigration. Stat. Sinica, 14: 1037-1055.

Barker, R.J. and G.C. White. - 2001. Joint analysis of live and dead encounters of marked animals. In: R. Field, R.J. Warren, H. Okarma and P.R. Sievert (eds.), Wildlife, Land, and People: Priorities for the 21st Century, Proc. 2nd Int. Wildl. Manag. Cong. The Wildlife Society, Bethesda, Maryland, USA, pp. 361-367.

Bjorndal, K.A., A.B. Bolten and M.Y.Chaloupka. - 2003a. Survival probability estimates for immature green turtles Chelonia mydas in the Bahamas. Mar. Ecol. Prog. Ser., 252: 273-281.

Bjorndal, K.A., A.B. Bolten and H.R. Martins. - 2003b. Estimates of survival probabilities for oceanic-stage loggerhead sea turtles (Caretta caretta) in the North Atlantic. Fish. Bull., 101: 732-736.

Bolten, A.B. - 1999. Techniques for measuring sea turtles. In: K.L. Eckert, K.A. Bjorndal, F.A. Abreu-Grobois and M. Donnelly (eds.), Research and Management Techniques for the Conservation of Sea Turtles. IUCN/SSC Mar Turtle Spec Group Publication 4, pp. 110-114.

Burnham, K.P. - 1993. A theory for combined analysis of ring recovery and recapture data. In: J.D. Lebreton and P.M. North (eds.), Marked individuals in the study of bird population, pp. 199-213, Birkhauser Verlag, Basel, Switzerland.

Bowen, B., J.C. Avise, J.I. Richardson, A.B. Meylan, D. Margaritoulis and S.R. Hopkins-Murphy. - 1993. Population structure of loggerhead turtles (Caretta caretta) in the northwestern Atlantic Ocean and Mediterranean Sea. Conserv. Biol., 7: 834-844

Casale, P., Laurent, L. and G. De Metrio. - 2004. Incidental capture of marine turtles by the Italian trawl fishery in the north Adriatic Sea. Biol. Conserv., 119(3): 287-295.

Casale, P., D. Freggi, R. Basso and R. Argano. - 2005. Size at male puberty, sexing methods, and adult sex ratio in loggerhead turtles (Caretta caretta) from Italian waters investigated through tail measurements. Herp. J., 15: 145-148.

Casale, P., N. Zizzo, M.Affronte, D. Freggi, R. Basso, C. Vallini, V. Prunella, R. Argano and M. Rocco. - (in press). Evidence of human-induced mortality among turtles stranded along Italian coasts. Proc. 25th Ann. Symp. Sea Turtle Biol. Conserv. 
Chaloupka, M. - 2003. Stochastic simulation modelling of loggerhead population dynamics given exposure to competing mortality risks in the Western South Pacific. In: A.B. Bolten and B. Witherington (eds.), Loggerhead Sea Turtles, pp. 274-294, Smithsonian Institution Press, Washington, DC, USA.

Chaloupka, M. and C. Limpus. - 1997. Heuristic simulation modelling of trawl fishery impacts on sGBR loggerhead population dynamics. In: S.P. Epperly and J. Braun (comps.), Proc. 17th Ann. Symp. Sea Turtle Biol. Conserv. NOAA Technical Memorandum NMFS-SEFSC-415, pp. 26-29.

Chaloupka, M.Y. and C.J. Limpus. - 2002. Survival probability estimates for the endangered loggerhead sea turtle resident in southern Great Barrier Reef waters. Mar. Biol., 140: 267-277.

Chaloupka, M.Y. and C.J. Limpus. - 2005. Estimates of sex- and age-class-specific probabilities for a southern Great Barrier Reef green turtle population. Mar. Biol., 146: 1251-1261.

Chaloupka, M.Y. and J.A. Musick. - 1997. Age, growth and population dynamics. In: P.L. Lutz and J.A. Musick (eds.), The biology of sea turtles, pp. 233-275, CRC Press, LLC.

Cooch, E. and G. White. - 2002. Using MARK-A gentle introduction. Electronic Book. http://www.phidot.org/software/mark/ docs/book/

Cormack, R.M. - 1964. Estimates of survival from the sighting of marked animals. Biometrika, 51: 429-438.

Dodd, C.K. Jr. - 1988. Synopsis of the biological data on the loggerhead sea turtle Caretta caretta (Linnaeus 1758). U.S. Fish Wildl. Serv., Biol. Rep. 88(14).

Epperly, S.P., M.L. Snover, J. Braun-McNeill, W.N. Witzell, C.A. Brown, L.A. Csuzdi, W.G. Teas, L.B. Crowder and R.A. Myers. - 2001. Stock assessment of loggerhead sea turtles of the western North Atlantic. NOAA Tech. Memo. NMFSSEFSC-455.

Frazer, N.B. - 1983. Demography and life history evolution of the Atlantic loggerhead sea turtle, Caretta caretta. PhD Dissertation, University of Georgia, Athens, Georgia USA.

Frazer, N.B. - 1987. Preliminary estimates of survivorship for wild juvenile loggerhead sea turtles (Caretta caretta). J. Herp., 2: 232-235.

Frederiksen, M and T. Bregnballe. - 2000. Evidence for densitydependent survival in adult cormorants from a combined analysis of recoveries and resightings. J. Anim. Ecol., 69: 737-752.

Gerosa, G. and P. Casale. - 1999. Interaction of Marine Turtles with Fisheries in the Mediterranean. UNEP-MAP-RAC/SPA, Tunis.

Heppell, S.S., C.J. Limpus, D.T. Crouse, N.B. Frazer and L.B. Crowder. - 1996. Population model analysis for the loggerhead sea turtle, Caretta caretta, in Queensland. Wildl. Res., 23: 143-159.

Heppell, S.S., M.L. Snover and L.B. Crowder. - 2003a. Sea turtle population Ecology. In: P.L. Lutz, J.A. Musick and J. Wyneken (eds.), The Biology of Sea Turtles, vol. II, pp. 275-306, CRC Press, Boca Raton.

Heppell, S.S., Crowder, L.B., Crouse, D.T., Epperly, S.P. and N.B. Frazer. - 2003b. Population Models for Atlantic Loggerheads: Past, Present, and Future. In: A.B. Bolten and B.E. Witherington (eds.), Loggerhead Sea Turtles, pp. 255-273, Smithsonian Books, Washington, D.C.

Jolly, G.M. - 1965. Explicit estimates from capture-recapture data with both death and immigration stochastic model. Biometrika, 52: 225-247.
Kopsida, H., D. Margaritoulis and D. Dimopoulos. - 2002. What marine turtle strandings can tell us. In: A. Mosier, A. Foley and B. Brost (comps.), Proc. 20th Ann. Symp. Sea Turtle Biol. Conserv. NOAA Technical Memorandum NMFS-SEFSC-477, pp. 207-209.

Laurent, L., P. Casale, M.N. Bradai, B.J. Godley, G. Gerosa, A.C. Broderick, W. Schroth, B. Schierwater, A.M. Levy, D. Freggi, E.M. Abd El-Mawla, D.A. Hadoud, H.E. Gomati, M. Domingo, M. Hadjichristophorou, L. Kornaraky, F. Demirayak and Ch. Gautier. - 1998. Molecular resolution of marine turtle stock composition in fishery bycatch: a case study in the Mediterranean. Mol. Ecol., 7: 1529-1542.

Lebreton, J.-D., K.P. Burnham, J. Clobert and D.R. Anderson. 1992. Modeling survival and testing biological hypotheses using marked animals: case studies and recent advances. Ecol. Monogr., 62: 67-118.

Limpus, C.J. - 1990. Puberty and first breeding in Caretta caretta. In: T.H. Richardson, J.I. Richardson and M. Donnelly (comps), Proc. 10th Ann. Works. Sea Turtle Biol. Conserv. NOAA Technical Memorandum NMFS-SEFC-278, pp. 81-83.

Limpus, C.J. - 1992. Estimation of tag loss in marine turtle research. Wildl. Res., 19(4): 457-469.

Lutcavage, M.E., Plotkin, P., Witherington, B., Lutz, P.I., 1997. Human impact on sea turtle survival. In: P.L. Lutz and J.A. Musick (eds.), The biology of sea turtles, pp. 387-411, CRC Press, LLC.

Margaritoulis, D., R. Argano, I. Baran, F. Bentivegna, M.N. Bradai, J.A. Caminas, P. Casale, G. De Metrio, A. Demetropoulos, G. Gerosa, B. Godley, J. Houghton, L. Laurent and B. Lazar. 2003. Loggerhead turtles in the Mediterranean Sea: present knowledge and conservation perspectives. In: A.B. Bolten and B. Witherington (eds.), Loggerhead Sea Turtles, pp. 175-198, Smithsonian Institution Press, Washington, DC, USA.

Pollock, K.H., J.D. Nichols, C. Brownie and J.E. Hines. - 1990. Statistical inference for capture-recapture experiments. Wildl. Monogr., 107.

Schaub, M. and R. Pradel. - 2004. Assessing the relative importance of different sources of mortality from recoveries of marked animals. Ecology, 85(4): 930-938.

Schroth, W., B. Streit and B. Schierwater. - 1996. Evolutionary handicap for turtles. Nature, 384: 521-522.

Seber, G.A.F. - 1965. A note on the multiple recapture census. Biometrika, 52: 249-259.

Seminoff, J.A., T.T. Jones, A. Resendiz, W.J. Nichols and M.Y. Chaloupka. - 2003. Monitoring green turtles (Chelonia mydas) at a coastal foraging area in Baja California, Mexico: Using multiple indices to describe population status. J.Mar. Biol. Ass. UK, 83: 1355-1362.

Tavecchia, G., R. Pradel, J.-D. Lebreton, A.L. Johnson and J.-Y. Mondain-Monval. - 2001. The effect of lead exposure on survival of adult mallards in the Camargue, southern France. $J$. Appl. Ecol., 38: 1197-1207.

White, G.C. and K.P. Burnham. - 1999. Program MARK: survival estimation from populations of marked animals. Bird. Study, 46(Suppl.): 120-138.

Scient. ed.: D. Oro.

Received December 12, 2006. Accepted February 22, 2007.

Publiseh online May 24, 2007. 